\title{
Rearing river lamprey Lampetra fluviatilis (L.) larvae under controlled conditions as a tool for restitution of endangered populations
}

\author{
Roman Kujawa ${ }^{1}$ - Dorota Fopp-Bayat ${ }^{2}$. \\ Beata I. Cejko ${ }^{3}$ - Dariusz Kucharczyk ${ }^{1}$. \\ Katarzyna Glińska-Lewczuk ${ }^{4} \cdot$ Krystian Obolewski $^{5}$ • \\ Mateusz Biegaj ${ }^{1}$
}

Received: 5 January 2017 / Accepted: 8 September 2017 /Published online: 15 September 2017

(C) The Author(s) 2017. This article is an open access publication

\begin{abstract}
A method for actively protecting river lamprey and increasing the number of river lamprey populations is presented as protocol of rearing stocking material. The objective of the study was to accommodate lamprey larvae during the most critical life period under controlled conditions until they reach a sufficient size, which will increase their chances to survive in the natural environment. The eggs obtained from wild breeders were incubated in Weiss's jars at the water temperature of $12{ }^{\circ} \mathrm{C}$. The larvae were reared in tanks set up in closed recirculating aquaculture systems. During the rearing period, the water temperature was $20{ }^{\circ} \mathrm{C}$ and the density of larvae was 150 individuals per $1 \mathrm{dm}^{2}$ of bottom. In the initial rearing phase, the main focus was on the type of feeds and the nourishment method. It was determined that the most suitable feed type was Artemia nauplii combined with Hikari dry food. Additionally, the type of substrate was tested under controlled conditions. In this case, the optimum one was
\end{abstract}

Electronic supplementary material The online version of this article (https://doi.org/10.1007/s10499-0170190-6) contains supplementary material, which is available to authorized users.

Dariusz Kucharczyk

darekk56@gmail.com

1 Department of Lake and River Fisheries, Faculty of Environmental Sciences, University of Warmia and Mazury, Olsztyn, Poland

2 Department of Ichtyology, Faculty of Environmental Sciences, University of Warmia and Mazury, Olsztyn, Poland

3 Department of Gamete and Embryo Biology, Institute of Animal Reproduction and Food Research, Polish Academy of Sciences, Olsztyn, Poland

4 Faculty of Environmental Management and Agriculture, Department of Water Resources, Climatology and Environmental Management, University of Warmia and Mazury, Olsztyn, Poland

5 Faculty of Natural Science Department of Hydrobiology, University in Bydgoszcz, Bydgoszcz, Poland 
composed of sand of the grain size between 0.3 and $0.5 \mathrm{~mm}$. The experiment proved that it is possible to successfully conduct river lamprey larvae rearing under controlled conditions. The growth rates are comparable to or better than those achieved under natural conditions. After 30 days of the rearing period, the lamprey larvae were $25 \mathrm{~mm}$ long. The results create a possibility to develop a technology for the restitution of river lamprey and other lamprey species, which are endangered throughout the world.

Keywords Aquaculture $\cdot$ Biodiversity $\cdot$ Brackish $\cdot$ Endangered species $\cdot$ Lamprey

$\begin{array}{ll}\text { Abbreviations } \\ \text { BW } & \text { Body weight } \\ \text { EN } & \text { Endangered species } \\ \text { ITL } & \text { Increase in total length } \\ \text { RFL } & \text { Relative final length } \\ \text { RGR } & \text { Relative growth rate } \\ \text { SD } & \text { Standard deviation }\end{array}$

\section{Introduction}

In Poland, as in whole Europe, some fish species as European eel Anguilla anguilla (Nowosad et al. 2014, 2015) and river lamprey Lampetra fluviatilis (Kujawa et al. 2016) belong to the species whose existence is gravely endangered. According to the IUCN/WCU classification, river lamprey is considered as an endangered species (EN) (Głowaciński 1992). Next to brook lamprey Lampetra planeri (Bloch, 1784) and sea lamprey Petromyzon marinus (Linnaeus, 1758), river lamprey is listed in Annex No. II to the EC Habitats Directive (92/43/EEC) of 21 May 1992 on the protection of natural habitats and wild fauna and flora (Sjöberg 1980; Maitland 1980; Renaud 2011). The river lamprey is a migratory, diadromous agnatha which attempts reproduction only once during its lifetime (Staff 1950; Brylińska 2000). In the larval stage, it prefers flowing waters, although actively foraging adults have a preference for sea waters. Recent results have shown that the most suitable temperature for maintaining lamprey adults and obtaining high-quality gametes is even lower, down to $7{ }^{\circ} \mathrm{C}$ (Cejko et al. 2016). Lampreys swimming to river in autumn go further inland and spawn at lower temperatures than those which migrate in spring and spawn at higher temperatures, even at $16^{\circ} \mathrm{C}$ (Ryapolova and Mitans 1991). In Poland, river lamprey spawning takes place when the water temperature exceeds $11-14{ }^{\circ} \mathrm{C}$ (Kujawa et al. 2016). Spawning does not take place in random locations, but usually where lamprey larvae are already present. In spring, lampreys start the spawning season and lay large amounts of eggs. After spawning, the breeders die within 1-3 weeks since they do not forage during the spawning trip and their digestive tract undergoes atrophy (Hardisty 1986).

In the wild, lamprey larvae after hatching settle in groups and bury themselves in mud in some river hollows where outwash and organic residues accumulate, sustaining the development of small algae and protozoans. The grain diameter of the substrate forming their microhabitats is usually $0.05-0.20 \mathrm{~mm}$ (Kainua and Valtonen 1980). Mortality during their lifecycle in the natural environment is very high, for example only $10 \%$ of lamprey larvae hatch during the incubation of eggs, of which $10 \%$ survive until metamorphosis. This means that only $1 \%$ of lamprey larvae reaches metamorphosis (Ryapolova 1990; Ryapolova and Mitans 1991). But study about rearing lamprey larvae under controlled conditions is still missing. 
In inland fisheries in past, river lamprey used to be perceived as a common species with a significant economic role (Staff 1950; Valtonen 1980; Birzaks and Abersons 2011). In Poland, catches of up to $80 \mathrm{t}$ per year were recorded until the end of the 1970s (Bartel 1992). By the late 1980 s, catches had dropped to approximately $900 \mathrm{~kg}$ per year. Recently, it has been noted that the distribution range of this species has started to diminish drastically. Studies on the condition of ichthyofauna in the Polish rivers have indicated a catastrophic reduction in river lamprey numbers (Kuszewski and Witkowski 1995; Witkowski and Kuszewski 1995; Witkowski et al. 1999). Such adverse changes in the occurrence of river lamprey have been noted not only in Polish waters, where this species has already become endangered, but also in other European inland water bodies (Maitland 2003; Nunn et al. 2008). In the world literature, the vast majority of data refer to the ecology and biology of sea lamprey and river lamprey (Jang and Lucas 2005). Few publications discuss the morphology and feeding of river lamprey in different water bodies and its preferences for habitats (Goodwin et al. 2008; Taverny et al. 2012; Aronsuu and Virkkala 2013). There are virtually no data on the reproduction of river lamprey under controlled conditions nor is there any information on its rearing in juvenile stages. Although there is some information concerning substrate selection by river lamprey larvae (Aronsuu 2015) and the rearing of other lamprey species, none of those publications deals with live food, which can play an important role in the early larval development of river lamprey (Mundahl et al. 2005; Barron et al. 2015; Lampman et al. 2016). Probably due to extinction of many lamprey populations, the study about its reproduction and rearing larvae under controlled conditions are very limited (Cejko et al. 2016). For this reason, such studies, which gave the possibility to produce in the future stocking material of lamprey, are needed.

The present study has involved placing larvae with the mostly absorbed yolk sac in appropriate pools, both with and without bottom substrate, and feeding them on finely grained feed, live Artemia salina (Linnaeus, 1758) nauplii and a combination of both. The objective was to accommodate larvae during the most critical period of their lives under controlled conditions until they reach a sufficient size, allowing them to survive in the natural environment.

\section{Materials and methods}

\section{River lamprey origin}

The study was carried out on river lamprey larvae originating from spawn incubated under controlled conditions, which was obtained from wild individuals caught at the turn of April and May in the Vistula Lagoon (Poland). To prevent spontaneous spawning, lamprey spawners (females and males) were placed in separate pools after being transported to the laboratory (Kujawa et al. 1999). Sex identification of spawners in the period preceding natural spawning did not present any problems. The spawners already had visible distinguishing features, which enabled recognition of their sex. Females presented a significantly enlarged abdominal area, whereas an elongated urogenital papilla was evident in males. The gametes were obtained from the fish after approximately 2 weeks (Kujawa 2014).

\section{River lamprey gamete collection and its fertilization}

The lampreys were anesthetized before sampling the sexual products because otherwise they would be very difficult to immobilize and the muscle tension would hinder collection 
of gametes (Kujawa 2014). To this end, a 2-phenoxyethanol solution (1.6 mL dm${ }^{-3}$ ) was administered (Lambooij et al. 2009). All spawners were measured $( \pm 0.1 \mathrm{~mm})$ and weighed $( \pm 0.1 \mathrm{~g})$ before collecting germ cells (Table 1). Precision balance KERN PBS6200-2 m (Germany) was used during weighing. The collected eggs was fertilized with semen obtained from several males by the method described by Kucharczyk et al. (2016) for freshwater finfish. After washing the eggs a few times, they were incubated in Weiss jars in water at $12{ }^{\circ} \mathrm{C}$. The incubation in water at this temperature lasted for 3 weeks. After hatching, larvae were kept for an additional 2 weeks in Weiss jars, where they absorbed the resources from the yolk sac.

\section{River lamprey larvae rearing}

River lamprey larvae with an almost reabsorbed yolk sac and starting to swim were put in aquaria with the bottom surface cover of 20 and $10 \mathrm{dm}^{2}$. Some of the pools had the bottom covered with a $15-\mathrm{mm}$ layer of washed sand [S] of the grain size of $0.3-0.5 \mathrm{~mm}$. Throughout the experiment, the only source of light was sunlight coming through the windows as no artificial lights were applied. Washed sand was chosen because it creates the best conditions for observations of the larvae and it contains little of organic substances which could be ingested as food by lamprey larvae, possibly affecting the rearing outcome. The aquaria were set up in a closed recirculation aquaculture system. The flow of water through the aquaria was $0.5 \mathrm{dm}^{3} \mathrm{~min}^{-1}$. The initial stock density of larvae in the individual pools was 150 individuals $\cdot \mathrm{dm}^{-2}$ bottom surface. The water temperature during the rearing was $20.0 \pm 0.5^{\circ} \mathrm{C}$. Dissolved oxygen level oscillated between 7.4 and $7.8 \mathrm{mg} \mathrm{dm}^{-3}$ and the $\mathrm{pH}$ was from 7.0 to 7.3. Ammonia and nitrate levels were measured during the experiment and no high levels (above $0.05 \mathrm{mg} \mathrm{dm}^{-3}$ ) of each was found (Nowosad et al. 2013). The first dose of feed was given to larvae $12 \mathrm{~h}$ after their transfer to the rearing tanks. Larvae were fed with live A. salina nauplii [A], Hikari feed [H], and a combination of both [A-H] (two replicates each), four times a day, every $4 \mathrm{~h}$. The rearing lasted 30 days. Natural food, namely live $A$. salina nauplii, was prepared according to the procedure described by Sorgeloos et al. (1977). The size of live A. salina nauplii (stage I) was $430 \mu \mathrm{m}$. The feed mixture was a specialized product: Hikari Plankton-Early Period Use. The pellet size ranged from 0.2 to $0.37 \mathrm{~mm}$. The composition of the natural food and feed mixture used in the experiment is presented in Table 2 .

\section{River lamprey larvae measurements}

During the study, any feed residue was removed each morning before feeding to ensure proper sanitary conditions and to prevent ammonia formation in water.

Table 1 Description of river lamprey (Lampetra fluviatilis L.) spawners from which sexual products were obtained

\begin{tabular}{lllll}
\hline Statistical measures & $\begin{array}{l}\text { Weight }(\mathrm{g}) \\
\text { Female }(n=10)\end{array}$ & Length $(\mathrm{mm})$ & $\begin{array}{l}\text { Weight }(\mathrm{g}) \\
\text { Male }(n=5)\end{array}$ & Length $(\mathrm{mm})$ \\
\hline $\min -\mathrm{max}$. & $128.5-178.0$ & $410.0-458.0$ & $93.5-125.5$ & $365.0-415.0$ \\
$(\bar{x})$ & 145.83 & 429.4 & 108.35 & 394.00 \\
$( \pm \mathrm{SD})$ & 16.23 & 14.07 & 11.91 & 18.31 \\
\hline
\end{tabular}


Table 2 Chemical composition of $A$. nauplii $*$ and starter diets produced by Hikari** (\% dry weight) (* data by P Candreva. Inve Aquaculture NV Dendermonde, Belgium; ** KYORIN CO., LTD. Japan)

\begin{tabular}{lllll}
\hline Food & \multicolumn{3}{l}{ Component (\%) } \\
\hline & Protein & Fat & Carbohydrate & Ash \\
Hikari Plankton & 48 & 3 & 2 & 18 \\
Micro artemia cysts & 54 & 11 & 5 & 6 \\
\hline
\end{tabular}

A control sample of larvae was collected on the stocking day before the start of feeding. Subsequent samples (of 30 individuals each) were taken every 6 days. The samplings took place before feeding. Prior to taking measurements, caught larvae were anesthetized briefly in Propiscin solution. The choice of Propiscin was dictated by the fact that it allows to take pictures of larvae under the surface of water without greasy stains. The concentration of the solution $\left(0.3 \mathrm{~cm}^{3} \mathrm{dm}^{-3}\right)$ was determined based on the results of our previous experiments. The larvae were measured (longitudo totalis-1.t.) at the accuracy of $0.1 \mathrm{~mm}$. Following the measurements, the larvae were released back to the pools from which they had been caught. Next, based on the measurements, the relative growth rate (RGR) was calculated from the onset of feeding to the end of the experiment, according to the formula by Myszkowski (1997).

$$
\mathrm{RGR}=100\left(e^{\frac{\mathrm{SGR}}{100}-1}\right)
$$

Where SGR is the relative body growth rate and $e$ is the base of the natural logarithm.

The increase in total length $\left(\mathrm{mm}_{\text {day }}{ }^{-1}\right)$ was calculated based on the formula by Peńáz et al. (1989). Statistical differences in the mortality of larvae between the stocking groups were analyzed with the chi-square test (Sokal and Rohlf 1969). The null hypothesis $\left(\mathrm{H}_{0}\right)$ that mortality in the compared samples was the same was verified with the chi-square distribution.

In order to compare the results, the relative final length (RFL) of the larvae was calculated, assuming that the length of larvae in the pools with substrate and fed the combination of the feed mixture and nauplii was $100 \%$ (a) at the termination of the experiment.

$$
\mathrm{RFL}={\frac{a}{x_{1,2,3 \ldots}}}^{*} 100
$$

Where $a$ is the highest mean body length value and $x_{1,2,3 \ldots}$ is the mean body length value from each group.

Statistical differences between the experimental groups were determined with the Tukey test at $\alpha=0.05$. Comparison of the significance of differences was performed based on an analysis of variance (ANOVA) and multiple comparisons with the Tukey's procedure (HSD) (Duncan 1955). The level of significance was assumed at $\alpha=0.05$. Statistical processing of the results was performed with Excel 2013 and Statistica 10.0 software for Windows. Homogenity of variance (the Levene's test, $\alpha=0.05$ ) and normal distribution (the Shapiro-Wilk test, $\alpha=0.05$ ) of the data were examined before the selection of the tests.

Chi-squared test was calculated according to formula shown below.

$$
\chi^{2}=\sum \frac{(O-E)^{2}}{E}
$$

Where $O$ is the observed values and $E$ is the expected value. 


\section{Results}

The highest length gains in river lamprey larvae were recorded during the rearing on mixed feed and in the pools with sand substrate $[\mathrm{S} / \mathrm{A}-\mathrm{H}]$ (Table 3). On the last day of rearing, the average body length of river lamprey larvae in the pools with substrate and fed with nauplii and the feed mixture [S/A-H] was $25.7 \mathrm{~mm}$, whereas larvae fed only with the feed mixture $[\mathrm{S} / \mathrm{H}]$ or only with live brine shrimp (Artemia sp.) nauplii [S/A-H] averaged 22.4 and $23.7 \mathrm{~mm}$ long, respectively. Statistically significant differences in the average body length of river lamprey larvae in the variants with and without substrate were observed only from day 18 of rearing (Fig. 1).

Larvae reared in the pools without substrate had significantly lower body length gains (Fisher test (LSD), MS-3705, df-118.00). In this variant, larvae administered the combination of feed mixture and natural food $[\mathrm{A}-\mathrm{H}]$ were the largest (Table 3 ), but no significant difference was demonstrated between $[\mathrm{A}-\mathrm{H}]$ and $[\mathrm{H}]$ groups (ANOVA, $F=98,68$, $p=0,0000$; the Tukey's test (HSD), MS-2.4107; $\mathrm{df}=114 p \leq 0.05$ ). The survival of larvae at the end of rearing was significantly higher in the pools with sand substrate, where it ranged from 60.0 to $76.4 \%\left(\chi^{2}=237.924 ; \mathrm{df}=1\right.$, Chi-squared distribution value at $p=0.005$ was $\chi=7.879)$. In the pools without substrate, the survival rate did not exceed $50 \%$. The increase in total length (ITL) was between $0.24 \mathrm{~mm} \mathrm{day}^{-1}$ [A] and $0.54 \mathrm{~mm}^{-1}$ day $^{-1}$ [S/A-H]. The calculated RGR values for larvae fed with the combination of the feed mixture and nauplii in the pools with $[\mathrm{S} / \mathrm{A}-\mathrm{H}]$ and without $[\mathrm{A}-\mathrm{H}]$ substrate were 3.33 and $2.24 \%$ day $^{-1}$ and were the highest for the given feeding variant (Table 3). Similarly, the relative final length index (RFL) demonstrates that the rearing of lamprey larvae in pools with substrate is much more efficient.

\section{Discussion}

Rearing larvae under controlled conditions is a very important stage in the production of fish stocking material for restitution purposes (Palińska-Zarska et al. 2014; Kujawa et al. 2017).

Table 3 Results of rearing lamprey larvae (Lampetra fluviatilis L.) fed with Artemia and/or with Hikari

\begin{tabular}{|c|c|c|c|c|c|c|}
\hline Parameter & $\mathrm{S} / \mathrm{H}$ & S/A-H & $\mathrm{S} / \mathrm{A}$ & $\mathrm{H}$ & A-H & A \\
\hline $\begin{array}{l}\text { Initial mean body } \\
\text { length }(\mathrm{mm})\end{array}$ & $9.68 \pm 0.26$ & $9.63 \pm 0.25$ & $9.65 \pm 0.28$ & $9.61 \pm 0.26$ & $9.68 \pm 0.26$ & $9.68 \pm 0.27$ \\
\hline $\begin{array}{l}\text { Final mean body } \\
\text { length }(\mathrm{mm})\end{array}$ & $22.4 \pm 1.37^{\mathrm{b}}$ & $25.7 \pm 1.45^{\mathrm{a}}$ & $23.7 \pm 1.28 \mathrm{~b}^{\mathrm{b}}$ & $18.3 \pm 1.74^{\mathrm{c}}$ & $18.8 \pm 1.65^{\mathrm{c}}$ & $16.8 \pm 1.86^{\mathrm{d}}$ \\
\hline Initial stock (indiv.) & 1500 & 1500 & 1500 & 1500 & 1500 & 1500 \\
\hline Final stock (indiv.) & 913.6 & 1146 & 1073.6 & 630 & 732 & 512 \\
\hline Survival (\%) & $60.9^{\mathrm{a}}$ & $76.4^{\mathrm{b}}$ & $71.6^{\mathrm{c}}$ & $42^{\mathrm{d}}$ & $48.8^{\mathrm{e}}$ & $34.1^{\mathrm{f}}$ \\
\hline $\begin{array}{l}(\mathrm{ITL}) \\
\left(\mathrm{mm} \mathrm{day}^{-1}\right)\end{array}$ & 0.42 & 0.54 & 0.47 & 0.29 & 0.30 & 0.24 \\
\hline $\begin{array}{l}\text { (RGR) for length } \\
\left(\% \text { day }^{-1}\right)\end{array}$ & 2.84 & 3.33 & 3.04 & 2.17 & 2.24 & 1.85 \\
\hline$(\mathrm{RFL})(\%)$ & 87.16 & 100.00 & 92.22 & 71.21 & 73.15 & 65.37 \\
\hline
\end{tabular}

Mean value \pm S.D. Results in rows with the same letter superscript are not statistically significantly different (the Tukey's test (HSD), MS -2.4107 ; $\mathrm{df}=114 p \leq 0.05$ ) 


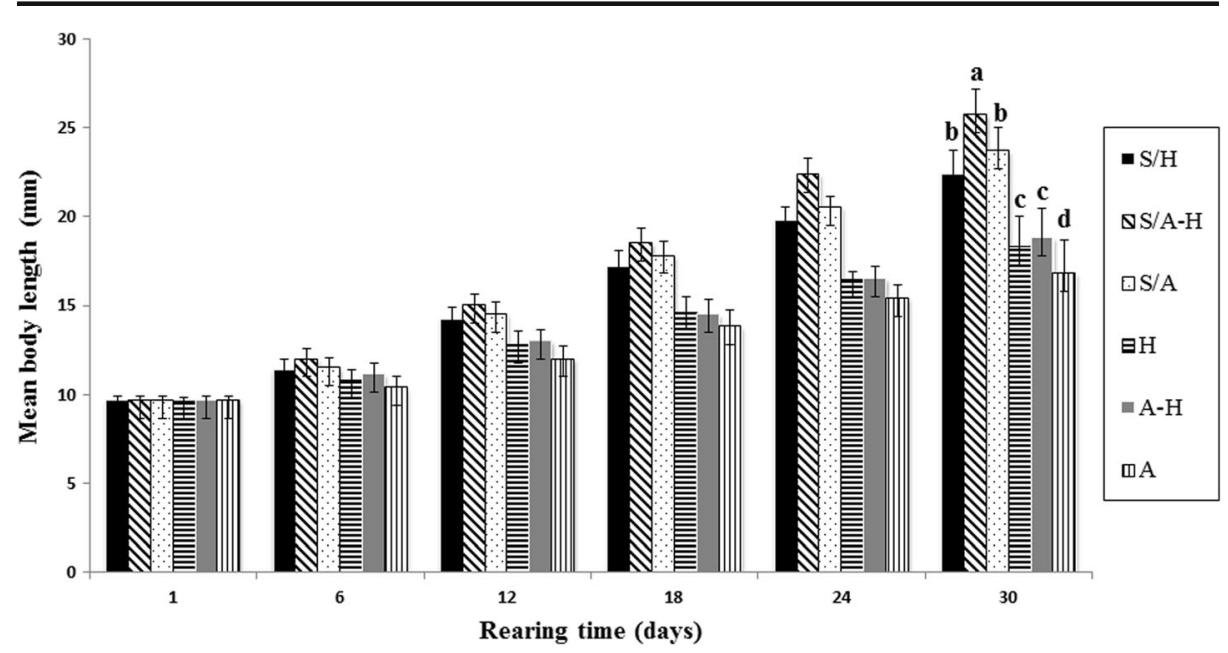

Fig. 1 Increase in body length (mean value $\pm \mathrm{SD}$ ) of lamprey larvae reared in the pools with and without substrate (sand). Different letters showing differences at $p<0.05$

Providing food with adequate quality and in proper amounts represents one of the major challenges faced during fish larvae rearing (Łączyńska et al. 2016). Similarly to fish larvae (Palińska-Zarska et al. 2014; Kujawa et al. 2017), lamprey larvae also start foraging when the yolk sac is mostly absorbed. The duration of a time period when fish larvae may use the resources accumulated in the yolk sac (Nowosad et al. 2017) before they start foraging on exogenous food depends on the water temperature at which incubation takes place and at which larvae are kept (Dabrowski 1976; Pepin 1991). In the present study, the applied food (Artemia nauplii and Hikari plankton) are appreciate kind of food for lamprey larvae.

For cyprinid larvae, feeding with feed mixtures from the very beginning results in smaller BW gains and lower survival than feeding with zooplankton (Mookerji and Rao 1991). They need a period of several days on natural food in order to be able to absorb the nutrients from feed mixtures afterwards (Nowosad et al. 2013; Łączyńska et al. 2016; Kujawa et al. 2017). Similar observations were made during the rearing of river lamprey larvae. Despite the higher availability of the feed mixture, larvae gained more body length and grew better on the mixed food supplemented with live A. salina nauplii.

A diet of lamprey larvae under controlled conditions consists mainly of organic detritus, which forces our constant search for new sources of nutrients easily accessible to larvae that can be used in rearing (Lampman et al. 2016). Until an adequate feed for river lamprey larvae is developed, they may be fed with commercial feed mixtures used for rearing fish larvae. However, such a feeding regime has to be preceded by several days of feeding larvae with natural food or a feed mixture combined with live A. salina nauplii (e.g., Palińska-Zarska et al., 2014; Łączyńska et al. 2016). This allows the larvae to achieve a rapid increase in body length and to progress through subsequent developmental stages. Improper food components might cause by larvae body deformations (Łaczyńska et al. 2016). Feed dosing may be automated with feeders (Charlon and Bergot 1984, 1986), which significantly reduces service costs. A rearing strategy based only on commercial feeds does not allow for full expression of the growth potential of larvae and therefore it is recommended to supplement them with live A. salina nauplii, which was also confirmed in previous studies carried out by Kujawa et al. (2010). There are few publications dealing with the rearing of Pacific and sea lamprey, where authors used to 
feed mainly yeast and algae (Mundahl et al. 2005; Barron et al. 2015; Lampman et al. 2016). Ryapolova and Mitans 1991 reared river lamprey larvae feeding them with boiled yeast (in $70{ }^{\circ} \mathrm{C}$ ) and once in 2 weeks they supplemented this diet with river sediments. But such kind of preparing food, especially for commercial scale, is difficult. As it is shown in this paper, rearing lamprey larvae using a different type of feed is possible as well. Moreover, live food is readily accessible to burrowed larvae and it ensures their high growth rates.

In the natural environment, lamprey larvae feed themselves by filtrating small particles from water, mainly zooplankton and phytoplankton and other organic particles (Mundahl et al. 2005). Since this is a pilot study, food with the composition comparable to natural food and composed of low-processed ingredients was used. Lamprey fry produced in this way may be used to restock selected river segments. During the restocking, a proper location for the release of larvae should be considered, including the type and structure of substrate and the velocity of a current. There should be some hollows or meanders, that is the sites where the river current decelerates and where outwash and organic residues accumulate, allowing for the robust growth of small algae and protozoans. The substrate should be up to $30 \mathrm{~cm}$ thick and composed of sand, silt, or mud. Densely overgrown sites and areas with clay ground should be avoided.

\section{Conclusions}

The success of the reintroduction of lamprey populations depends on the knowledge of their requirements for habitats. After several years, a correctly managed restocking operation carried out at appropriately chosen sites will generate an increase in the number of lampreys initially migrating to the sea and returning to spawning grounds after several months. Lamprey fry produced in this way may be used to restock selected river segments. During the restocking, a proper location for the release of larvae should be considered, including the type and structure of substrate and the velocity of a current. There should be some hollows or meanders, that is the sites where the river current decelerates and where outwash and organic residues accumulate, allowing for the robust growth of small algae and protozoans. The substrate should be up to $30 \mathrm{~cm}$ thick and composed of sand, silt, or mud. Densely overgrown sites and areas with clay ground should be avoided.

The success of the reintroduction of lamprey populations depends on the knowledge of their requirements for habitats. After several years, a correctly managed restocking operation carried out at appropriately chosen sites will generate an increase in the number of lampreys initially migrating to the sea and returning to spawning grounds after several months. Further studies on river lamprey larvae rearing under controlled conditions are recommended, with the emphasis on a type of substrate that ensures proper conditions for foraging larvae and that is also easy to remove during catches of larvae (Cejko et al. 2016).

Acknowledgments This research has been financed by the NCN the Polish National Science Centre under the research project number DEC-2013/09/B/NZ9/03130. Although experiments with river lamprey does not need any Animal Care Commision approval, the permission of General Director for Environmental Protection for obtaining adult lampreys from environment was obtained (Decision number DOPOZ.6401.10.3.2013.1s)

Open Access This article is distributed under the terms of the Creative Commons Attribution 4.0 International License (http://creativecommons.org/licenses/by/4.0/), which permits unrestricted use, distribution, and reproduction in any medium, provided you give appropriate credit to the original author(s) and the source, provide a link to the Creative Commons license, and indicate if changes were made. 


\section{References}

Aronsuu K (2015) Lotic life stages of the European River lamprey (Lampetra fluviatilis): anthropogenic detriment and rehabilitation. University Library of Jyväskylä, Jyväskylä

Aronsuu K, Virkkala P (2013) Substrate selection by subyearling European river lampreys (Lampetra fluviatilis) and older larvae (Lampetra spp). Ecol Freshw Fish 23:644-655. https://doi.org/10.1111/eff.12119

Barron JM, Twibel RG, Hill HA, Hanson KC, Gannam LA (2015) Development of diets for the intensive culture of Pacific lamprey. Aquac Res. https://doi.org/10.1111/are.12840

Bartel R (1992) Anadromous fish in the polish fish fauna. Messag Fish 2:22-25

Birzaks J, Abersons K (2011) Anthropogenic influence on the dynamics of the river lamprey Lampetra fluviatilis landings in the river Daugava Basin. Scientific journal of Riga Technical University. Environ Clim Technol 7:32-38. https://doi.org/10.2478/v10145-011-0025-z

Brylińska M (2000) Polish inland water fish. PWN, Warsaw (In Polish)

Cejko BI, Judycka S, Kujawa R (2016) The effect of different ambient temperatures on river lamprey (Lampetra fluviatilis) egg and sperm production under controlled conditions. J Thermal Bio 62:70-85. https://oi. org/10.1016/j.jtherbio.2016.09.011

Charlon N, Bergot P (1984) Rearing system for feeding fish larvae on dry diets. Trial with carp (Cyprinus arpio L.) larvae. Aquaculture 41:1-9. https://doi.org/10.1016/0044-8486(84)90384-3

Charlon N, Bergot P (1986) An improved automatic dry food dispenser for fish larvae. Prog Fish Cult 48:156158. https://doi.org/10.1577/1548-8640(1986)48<156:AIADFD>2.0.CO;2

Dabrowski K (1976) An attempt to determine the survival time for starving fish larvae. Aquaculture 8:189-193. https://doi.org/10.1016/S0044-8486(76)80074-9

Duncan DB (1955) Multiple range and multiple F-test. Biometrics 11:1-42. https://doi.org/10.2307/3001478

Głowaciński Z (1992) Polish red book of animals. PWRiL, Warsaw (In Polish)

Goodwin CE, Dick JTA, Rogowski DL, Elwood RW (2008) Lamprey (Lampetra fluviatilis and Lampetra planeri) ammocoete habitat associations at regional, catchment and microhabitat scales in Northern Ireland. Ecol Freshw Fish 17:542-553. https://doi.org/10.1111/j.1600-0633.2008.00305.x

Hardisty MW (1986) Lampetra fluviatilis (Linnaues, 1758). In: Holcik J (ed) The freshwater fishes of Europe, Part 1, vol 1. Petromyzontifomes, AULA-Verlag, Wiesbaden, pp 249-278

Jang MH, Lucas MC (2005) Reproductive ecology of the river lamprey. J Fish Biol 66:499-512. https://doi. org/10.1111/j.0022-1112.2005.00618.x

Kainua K, Valtonen T (1980) Distribution and abundance of European river lamprey (Lampetra fluviatilis) larvae in three rivers running into Bothanian Bay. Finland. Can J Fish Aquat Sci 37:1960-1966. https://doi. org/10.1139/f80-236

Kucharczyk D, Nowosad J, Łuczyński MJ, Targońska K (2016) New technique for fertilizing eggs of burbot, asp and ide under hatchery conditions. Anim Reprod Sci 172:143-147. https://doi.org/10.1016/j. anireprosci.2016.07.012

Kujawa R (2014) Preliminary studies concerning the possibility of reproduction river lamprey (Lampetra fluviatilis) under controlled conditions. In: Zakęś Z, Demska-Zakęś K, Kowalska A (eds) Wylęgarnictwo organizmów wodnych a bioróżnorodność. IRS, Olsztyn, pp 209-215 (In Polish)

Kujawa R, Biegaj M, Juchno D (2016) Habitat preferences of the river lamprey larvae (Lampetra fluviatilis). In: Zakęś Z, Demska-Zakęś K, Kowalska A (eds) Wylęgarnictwo, podchowy ryb i zarybienia. IRS, Olsztyn, pp 117-129 (In Polish)

Kujawa R, Kucharczyk D, Mamcarz A (1999) A model system for keeping spawners of wild and domestic fish before artificial spawning. Aquac Eng 20:85-89. https://doi.org/10.1016/S0144-8609(99)00004-7

Kujawa R, Kucharczyk D, Mamcarz A, Jamróz M, Kwiatkowski M, Targońska K, Żarski D (2010) Impact of supplementing natural feed with dry diets on the growth and survival of larval asp, Aspius aspius (L.), and nase, Chondrostoma nasus (L.) Arch Pol Fish 18:13-23. https://doi.org/10.2478/v10086-010-0002-3

Kujawa R, Lach M, Pol P, Ptaszkowski M, Mamcarz A, Nowosad J, Furgała-Selezniow G, Kucharczyk D (2017) Influence of water salinity on the survival of embryos and growth of the sichel larvae Pelecus cultratus (L.) under controlled conditions. Aquac Res 48(3):1302-1314. https://doi.org/10.1111/are.12972

Kuszewski J, Witkowski A (1995) Morphometrics of the autumn spring run populations of the river lamprey, Lampetra fluviatilis (Linnaeus, 1758) from the polish rivers. Acta Ichthyol Piscat 25:57-69

Łączyńska B, Palińska-Żarska K, Nowosad J, Biłas M, Krejszeff S, Müller T, Kucharczyk D, Żarski D (2016) Effect of age, size and digestive tract development on weaning effectiveness in crucian carp, Carassius carassius (Linnaeus, 1758). J App Ichthyol 32(5):866-872. https://doi.org/10.1111/jai.13100

Lambooij B, Pilarczyk M, Bialowas H, Reimert H, Andre G, Van de Vis H (2009) Anaesthetic properties of Propiscin (Etomidaat) and 2-phenoxyethanol in the common carp (Cyprinus carpio L.), neural and behavioural measures. Aquacul Res 40:1328-1333. https://doi.org/10.1111/j.1365-2109.2009.02233.x 
Lampman R, Moser M, Jackson A, Rose R, Gannam A, Barron J (2016) Developing techniques for artificial propagation and early rearing of Pacific lamprey (Entosphenus tridentatus) for species recovery and restoration. In: Orlov A, Beamish R (eds) Jawless fishes of the world. Cambridge Scholars Publishing, Newcastle, pp 160-195

Maitland PS (2003) Ecology of the river, brook and se lamprey. Conserving Natura 2000 Rivers Monitoring Series No.5. English Nature, Peterborough, p 52

Maitland PS (1980) Review of the ecology of lampreys in northern Europe. Can J Fish Aquat Sci 37:1944-1952. https://doi.org/10.1139/f80-234

Mookerji N, Rao TR (1991) Survival and growth of rohu (Labeo rohita) and singhi (Heteropneustes fossilis) larvae fed on dry and live foods. Spec Publ Eur Aquacult Soc 15:148-150

Mundahl ND, Erickson C, Johnson MR, Sayeed GA, Taubel S (2005) Diet, feeding rate, and assimilation efficiency of American brook lamprey larvae. Environ Biol Fish 72:67-72. https://doi.org/10.1007/s10641004-6591-1

Myszkowski L (1997) Pitfalls of using growth rate coefficients. Pol Arch Hydrobiol 44:389-396

Nowosad J, Zarski D, Biłas M, Dryl K, Krejszeff S, Kucharczyk D (2013) Dynamics of ammonia excretion in juvenile common tench, Tinca tinca (L.), during intensive rearing under controlled conditions. Aquacult Int 21(3):629-637. https://doi.org/10.1007/s10499-012-9596-3

Nowosad J, Kucharczyk D, Czarkowski TK, Kwasek K (2014) Changes in body weight and eye size in female European eel kept in fresh and salt water. Ital J Ani Sci 13:382-386

Nowosad J, Kucharczyk D, Łuczyńska J, Targońska K, Czarkowski TK, Biłas M, Krejszeff S, Horvath L, Muller $\mathrm{T}$ (2015) Changes in European eel ovary development and body and ovary chemistry during stimulated maturation under controlled conditions: preliminary data. Aquacult Int 23:13-27

Nowosad J, Kucharczyk D, Targońska K (2017) Enrichment of zebrafish Danio rerio (Hamilton, 1822) diet with PUFAs improves fecundity and larvae quality. Zebrafish 14(4):364-370. https://doi.org/10.1089 /zeb.2017.1416

Nunn AD, Harvey JP, Noble RAA, Cowx IG (2008) Condition assessment of lamprey populations in the Yorkshire Ouse catchment, north-east England, and the potential influence of physical migration barriers. Aquat Conserv 18:175-189. https://doi.org/10.1002/aqc.863

Palińska-Zarska K, Zarski D, Krejszeff S, Nowosad J, Biłas M, Trejchel K, Kucharczyk D (2014) Dynamics of yolk sac and oil droplet utilization and behavioural aspects of swim bladder inflation in burbot, Lota lota L., larvae during the first days of life, under laboratory conditions. Aquacult Int 22:13-27. https://doi. org/10.1007/s10499-013-9663-4

Peňáz M, Prokeš M, Kouřil J, Hamáčková J (1989) Influence of water temperature on the early development and growth of the tench, Tinca tinca. Folia Zool 38:275-287

Pepin P (1991) Effect of temperature and size on development, mortality, and survival rates of the pelagic early life history stages of marine fish. Can J Fish Aquat Sci 48:503-518. https://doi.org/10.1139/f91-065

Renaud CB (2011) Lampreys of the world. FAO species catalogue for fishery purposes no.5, food and agriculture organization of the United States, Rome

Ryapolova N (1990) Biotechnics of river lamprey artificial propogation. Modern meens of reproduction and exploitation of water biological resources. Inrybprom-90. Moscow (in Russian)

Ryapolova NI, Mitans AR (1991) Biological background and biotechnical principles of river lamprey (Lampetra fluviatilis) hatchery reproduction. Aquaculture at the Baltics. Avots, Riga, pp 84-99 (in Russian)

Sjöberg K (1980) Ecology of the European River lamprey (Lampetra fluviatilis) in northern Sweden. Can J Fish Aquat Sci 37:1974-1980. https://doi.org/10.1139/f80-238

Sokal RR, Rohlf JR (1969) Biometry. The principles and practice of statistics in biological research. H.F. Freeman and Co., San Francisco

Sorgeloos P, Bossuyt E, Lavina E, Baeza-Mesa M, Persoone G (1977) Decapsulation of Artemia cysts: a simple technique for the improvement of the use of brine shrimp in aquaculture. Aquaculture 12:311-315. https://doi.org/10.1016/0044-8486(77)90209-5

Staff F (1950) Polish freshwater fish and neighboring countries. Trzaska, Evert i Machalski, Warsaw (In Polish)

Taverny C, Lassalle G, Ortusi I, Roqueplo C, Lepage M, Lambert P (2012) From shallow to deep waters: habitats used by larval lampreys (genus Petromyzon and Lampetra) over a western European basin. Ecol Freshw Fish 21:87-99. https://doi.org/10.1111/j.1600-0633.2011.00526.x

Valtonen T (1980) European river lamprey (Lampetra fluviatilis) fishing and lamprey populations in some rivers running into Bothnian Bay, Finland. Can J Fish Aquat Sci 37:1967-1973. https://doi.org/10.1139/f80-237

Witkowski A, Błachuta J, Kotusz J (1999) Red list of freshwater fish fauna Polish. Chrońmy Przyrodę Ojczystą 55:5-19 (In Polish)

Witkowski A, Kuszewski A (1995) Characteristics of the population of Lampetra fluviatilis (L.) entering the Drwęca and Grabowa rivers (north Poland). Acta Ichthyol Piscat 25:49-55 